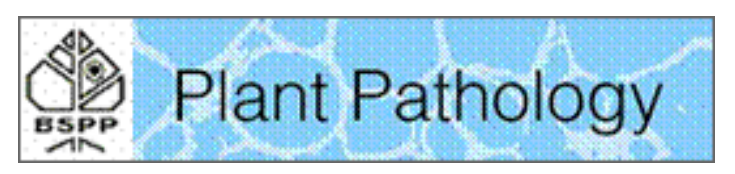

\title{
Phytophthora oleae, a new root pathogen of wild olives
}

\begin{tabular}{|r|l|}
\hline Journal: & Plant Pathology \\
\hline Manuscript ID & PP-19-064.R2 \\
\hline Manuscript Type: & Original Article \\
\hline Date Submitted by the \\
Author: & 15-Mar-2019 \\
\hline Complete List of Authors: & $\begin{array}{l}\text { González, Mario; ETSIAM } \\
\text { Pérez-Sierra, Ana; Forest Research } \\
\text { Sanchez, Maria; ETSIAM }\end{array}$ \\
\hline Topics: & aetiology, epidemiology \\
\hline Organisms: & oomycetes \\
\hline Other Keywords: & $\begin{array}{l}\text { decline, Natural Reserve, Olea europaea var. sylvestris, invasive } \\
\text { pathogen }\end{array}$ \\
\hline &
\end{tabular}


3

4

5

6

7

8

9

\title{
Phytophthora oleae, a new root pathogen of wild olives
}

\author{
M. González ${ }^{\mathrm{a}}$ A. Pérez-Sierra ${ }^{\mathrm{b}}$, M.E. Sánchez ${ }^{\mathrm{a}^{*}}$
}

aAgronomy Department, ETSIAM, Universidad de Córdoba, Ctra. Madrid-Cádiz 396, 14014-Córdoba, Spain; ${ }^{b}$ Tree Health Diagnostic and Advisory Service, Forest Research, Alice Holt Lodge, GU10 4LH, Farnham, UK

*Corresponding author: María Esperanza Sánchez - e-mail: ag1sahem@uco.es

Telephone number: +34957212425

\section{Abstract}

Wild olive (Olea europaea subsp. europaea var. sylvestris) is an important component of Mediterranean forests and a key genetic source for olive improvement programs. Since 2009, a severe decline caused by Phytophthora cryptogea and P. megasperma was detected in a protected wild olive forest of high ecological value (Dehesa de Abajo, Seville, Spain). In this natural forest, samplings of roots and soil were done on 25 symptomatic wild-olives in 2014 and 2015. Apart from the already known P. cryptogea A1 and P. megasperma, a third Phytopththora species was consistently isolated from symptomatic wild-olive rootlets. These isolates conformed morphologically with the newly described species $P$. oleae and were confirmed by analysis of their ITS regions and Cox-1 sequences. Temperature-growth relationships showed a maximum growth at $19.9^{\circ} \mathrm{C}$ on CA medium, being the lowest-temperature Phytophthora spp. infecting wild olive roots. Pathogenicity was confirmed on 1 year-old healthy wild olive seedlings and was similar respect to the previously known pathogenic Phytophthoras. As temperature requirements are quite different, the three Phytophthora spp. may be active against wild 
olive roots in different seasons. However, the prevalence of $P$. oleae infecting wild olives in the last years could be due to its introduction as a new invasive pathogen. The likely invasive nature of $P$. oleae, together with increasing rain episodes concentrated in short periods frequent in southern Spain, would allow outbreak infections in wild olive forests, also putting at risk cultivated olive orchards.

Keywords: decline, invasive pathogen, Natural Reserve, Olea europaea var. sylvestris,

\section{Introduction}

Olive (Olea europaea subsp. europaea) is a fruit crop widely distributed in the Mediterranean region with economically important cultivars and also wild genotypes growing in natural forests. In Spain, the wild form (O. europaea subsp. europaea var. sylvestris) represents a distinct botanical variety of the subspecies europaea and is considered the best bioindicator of the Mediterranean Floristic Region (Rubio de Casas et al., 2002). Moreover, wild olives represent the main source of genetic traits for improvement of cultivated forms, commonly used in breeding programs for the high degree of resistance to diseases showed by some genotypes (Arias-Calderón et al., 2015).

Recently, a wild olive root rot caused by Phytophthora megasperma and P. cryptogea was reported in a Natural Reserve in southern Spain (Dehesa de Abajo, Seville) affecting near 5 ha of wild olive woodland of high ecological value (González et al 2017a). This forest grows around a natural pond with marked fluctuations in water tables due to the seasonal distribution of rainfall, alternating seasonal soil flooding and drought periods. As expected for Phytophthora soilborne pathogens, affected trees 
54 exhibited different degree of symptoms depending on their distribution: moderate 55 defoliation uphills, while severe defoliation and tree death were recorded downhills. Phytophthora megasperma was the only species isolated from declining wild olives in 2009. However, P. cryptogea was the main species associated with wild olive root disease in 2013 (González et al., 2017a). It was hypothesized that a higher-temperature P. cryptogea could replace the lower-temperature $P$. megasperma as a result of the global increase in temperatures in the Mediterranean region due to global climate change (Lindner et al., 2010). Given the intrinsic ecological and genetic value of wild olive populations, the main objective of this work was to know the evolution of Phytophthora spp. associated with the root disease, clarifying the role of temperature in the disease aetiology. Additionally, a new Phytophthora spp. associated with necrotic roots was isolated, identified, temperature-characterized, and checked for pathogenicity on wild olive.

\section{Materials and methods}

\section{Samplings and isolations}

In November 2014 and November 2015, two field surveys were carried out at the Natural Reserve "Dehesa de Abajo" (Seville, Spain, UTM 29: 37¹2’33'’N; $\left.6^{\circ} 10^{\prime} 16^{\prime \prime} \mathrm{W}\right)$. Soil is a mixture of gravel and sand with rainfall rates averaging $648 \mathrm{~mm}$ per year, mainly distributed in autumn and winter (Consejería de Agricultura, Pesca y Desarrollo Rural, 2017). Cardinal temperatures (minimum and maximum) recorded in the period 2001-2015 at the nearest meteorological station (La Puebla del Río II 
Meteorological station; $37^{\circ} 04^{\prime} 48^{\prime}$ ' $\mathrm{N}, 06^{\circ} 02^{\prime} 47^{\prime}$ ' $\mathrm{W}$, altitude 41 m.a.s.l.) are summarized in Table 1.

Using the methodology described in González et al. (2017a), samples of rootlets and rhizosphere soil were taken at approximately $1 \mathrm{~m}$ distance from the trunk at $10-30 \mathrm{~cm}$ depth of a total of 25 symptomatic (crown wilting or/and defoliation) wild olives. Samples from different trees were independently processed. For each sample, rotten feeder roots were cut in 3-4 mm segments, washed under running water for $2 \mathrm{~h}$, and directly plated on NARPH medium (Hüberli et al., 2000). Soil samples were air dried and sieved $(2 \mathrm{~mm})$ and isolations from soil were performed using pieces of newly formed olive leaves as baits, according with González et al. (2017a). Six beakers per sample with a soil-water mixture (15:200 w:vol) and six floating baits each one, were incubated for 4 days at $22^{\circ} \mathrm{C}$ under $12 \mathrm{~h}$ photoperiod. After the incubation period, the leaf pieces were washed and plated in Petri dishes containing NARPH medium. All the dishes (roots and soil baits) were incubated at $22^{\circ} \mathrm{C}$ in the dark for 4 days. Colonies obtained from damaged roots and soil baits were grouped according to their morphology and transferred to $20 \%$ carrot agar (CA) medium. Five isolates per colony morphology were selected among the pure cultures obtained for molecular and morphological identification and growth-temperature characterization.

\section{DNA extraction, amplification and sequencing}

DNA of the isolates was obtained by harvesting the mycelium from 1-week-old pure cultures grown on PDA at $20^{\circ} \mathrm{C}$ in the dark. DNA was extracted using the PowerSoil DNeasy kit (Qiagen) following the manufacturer's protocol. The internal transcribed spacer (ITS1-5.8S-ITS2) region of the rDNA was amplified by PCR using the universal 
103 primers ITS-6 (Cooke et al., 2000) and ITS-4 (White et al., 1990). The PCR reaction conditions used were an initial denaturing step of $94^{\circ} \mathrm{C}$ for 2 min followed by 35 cycles of $94^{\circ} \mathrm{C}$ for $30 \mathrm{~s}$, annealing at $55^{\circ} \mathrm{C}$ for $30 \mathrm{~s}$ and an extension at $72^{\circ} \mathrm{C}$ for $45 \mathrm{~s}$, with a final extension of $72^{\circ} \mathrm{C}$ for $10 \mathrm{~min}$. The mitochondrial cox 1 gene was amplified using final extension of $5 \mathrm{~min}$ at $72^{\circ} \mathrm{C}$ (Ruano-Rosa et al., 2018).

\section{Morphological and growth-temperature characterization}

For isolates molecularly identified but not previously associated with wild olive root rot, a morphological and growth-temperature characterization were carried out.

To characterize colony morphologies, the five selected isolates were grown at $20^{\circ} \mathrm{C}$ in the dark on CA and PDA medium for 5 days to describe colony colour, pattern, edge shape and presence of aerial mycelium.

119 To describe sexual structures (oogonia, antheridia and oospores), isolates were individually transferred onto $\mathrm{CA}$ medium, incubated at $22^{\circ} \mathrm{C}$ in the dark, and periodically observed under the inverted microscope (Olympus IMT-2, 40×). When sexual reproductive structures were detected in single cultures (after 10 days of incubation), small pieces of agar were placed on glass slides, stained with acid fuchsin in lactophenol $(0.0005 \%)$ and observed under the microscope (Nikon Eclipse 80i, $100 \times)$. For each isolate, 30 mature oogonia, 30 antheridia and 30 oospores were selected and measured (NIS-Elements D 2.30, Nikon Instruments): oogonium and oospore diameter, antheridium length and thickness of the oospore wall. 
128 To characterize asexual structures (sporangia), small CA plugs (5 $\mathrm{mm}$ diameter) from the edges of actively growing colonies were placed in the centre of 5-cm-diameter Petri dishes, and after that, sterilized saline solution (MSS, Chen \& Zentmyer, 1970) was added to just cover the agar plugs. Petri dishes were incubated in darkness at $20^{\circ} \mathrm{C}$. Every $24 \mathrm{~h}$, the saline solution was removed and replaced with fresh solution. After 4 days of incubation, mature sporangia present in the floating mycelium were removed and placed on glass microscope slides and stained with acid fuchsin in lactophenol $(0.0005 \%)$ for observation under the microscope (Nikon Eclipse 80i, 100×). For each isolate, 30 mature sporangia were randomly chosen, and the following parameters were measured (NIS-Elements D 2.30, Nikon Instruments): sporangium length and breadth, and pore width. Other sporangial characteristics such as shape, presence or absence of papilla, were also recorded.

For growth rate tests, agar plugs of each isolate were plated in $9 \mathrm{~cm}$ Petri dishes with CA or PDA medium and incubated in the dark at $5,10,15,20,25,30$ or $35^{\circ} \mathrm{C}$. Three replicates (dishes) per isolate were prepared. Colony radius was measured daily until the colonies covered the agar surface and growth rate per day was calculated for each isolate, culture medium and incubation temperature. Maximum average data were adjusted to a regression curve using Statistix 10.0 for Windows (Analytical Software, Tallahassee, FL). The best polynomial model was chosen from several combinations of terms, based on the significance of the estimated parameters $(p<0.05)$, coefficients of determination $\left(\mathrm{R}^{2}\right)$, coefficients of determination adjusted by degrees of freedom $\left(\mathrm{R}_{\mathrm{a}}{ }^{2}\right)$, and pattern of residuals. Maximum growth rates and optimum growth temperatures were estimated over the regression curves obtained.

\section{Pathogenicity tests}


154 Healthy wild olive seedlings (1-year-old) from a forest nursery of the Andalusian

Government (Vivero San Jerónimo, Seville) were inoculated with one isolate of the

Phytophthora spp. newly associated with wild olive root disease (Po group). To prepare

157 the inoculum, colonized agar plugs were placed in $9 \mathrm{~cm}$ Petri dishes containing $20 \mathrm{ml}$ of $20 \%$ carrot broth and incubated at $22^{\circ} \mathrm{C}$ in the dark for 20 days. The mycelium produced was then filtered, washed, and shaken in an electric mixer (Osterizer pulse-matic 16)

with sterile water for $3 \mathrm{~min}$ at the highest speed to break mycelium masses and liberate oospores. Oospore concentration was estimated by counting in a Neubauer chamber and adjusted to $2.2 \times 10^{4}$ oospores $\times \mathrm{ml}^{-1}$. For inoculation, $50 \mathrm{ml}$ of this inoculum was homogeneously added to the root ball of each seedling, before transferring them into plastic pots containing 21 of soil (sand:lime:peat 1:1:1 vol.). Ten seedlings (replicates) were inoculated and 10 additional seedlings (uninoculated controls) were treated in the same way, but only $50 \mathrm{ml}$ of sterile water was applied to their root balls. All the pots were incubated in an acclimatized greenhouse and flooded 2 days per week (Romero et al., 2007). Foliar symptoms were assessed weekly for each seedling based on a $0-4$ scale, according to the percentage of yellowing, wilted foliage or defoliation recorded ( 0 $=0 \%, 1=1-33 \%, 2=34-66 \%, 3=$ more than $67 \%$ and $4=$ dead foliage) (Sánchez et al., 1998; González et al., 2017a). After 14 weeks, the relative area under the disease progress curve (rAUDPC) was calculated as percentage regarding the potential maximum value (Campbell \& Madden, 1990). At this moment, root symptoms were also assessed according to a similar 0-4 scale referred to root necrosis or rootlet absence percentage as follows: $0=0 \%, 1=1-33 \%, 2=34-66 \%, 3=$ more than $67 \%, 4=$ dead root (Sánchez et al., 1998; González et al., 2017a). 
177 Data on foliar and root symptoms at the end of the experiment and rAUDPCs were

178 tested for homocedasticity by the Levene's test and then, a one-way ANOVA was 179 performed, and mean values compared by the Tukey's HSD test for $\alpha=0.05$ (Statistix

180

181

182

183

184

185

186

187

188

189

190

191

192

193

194

195

196

197

198

199

200 software 10.0).

Additionally, root segments from inoculated or control plants were carefully washed and plated on NARPH medium for re-isolation of the pathogen.

\section{Results}

\section{Site temperatures}

Table 1 shows the mean values of minimum and maximum temperatures recorded at La Puebla del Río II Meteorological station, grouped by season, for the period 2007-2015 and the wider historical temperature series available (2001-2015). It is remarkable the occurrence of two exceptional cold episodes suffered in winter $2007\left(2.9^{\circ} \mathrm{C}\right)$ and winter $2012\left(3.1^{\circ} \mathrm{C}\right)$ in comparison with the mean of minimum temperatures registered in the historical series $\left(6.1^{\circ} \mathrm{C}\right)$.

\section{Species identification}

Three different groups of isolates respect to their colony morphology on CA were found (Pm, Pc, and Po). The sequences of the ITS rDNA region (99\% of homology with GenBank) conformed with $P$. megasperma $(\mathrm{Pm})$ and $P$. cryptogea $(\mathrm{Pc})$ as described in Gonzalez et al (2017a). 
201 The third group of isolates (Po) was morphologically described since it was not

202

203

204

205 previously known as associated with wild olive root rot. All these isolates showed colonies with scarce aerial mycelium and chrysanthemum growth pattern (Table 2). The sporangia of Po group were rarely produced in CA medium but very abundant in MSS saline solution. Gametangia were produced abundantly in CA single culture. Morphological characteristics of Po isolates are summarized in Table 2, and they were in good agreement with the description of P. citricola complex (Jung \& Burgess, 2009), which includes $P$. plurivora, $P$. multivora and $P$. citricola. The sequence analyses of ITS rDNA regions conformed with $P$. plurivora, but only with a 95\% homology with sequences in GenBank. Following the recent description of a new Phytophthora species, P. oleae (Ruano-Rosa et al., 2018), it was found that morphological data obtained for Po isolates were in a better agreement with features issued for P. oleae and, moreover, ITS rDNA regions and Cox-1 gene sequences conformed with $P$. oleae with a $100 \%$ homology.

\section{Growth-temperature relationships}

All five Po isolates had similar cardinal temperatures and growth rates at all temperatures. A $3^{\text {rd }}$ degree polynomic model was selected: $y=\mathrm{aT}^{3}+\mathrm{bT}^{2}+\mathrm{cT}+\mathrm{d}$, as the best expression of growth rate versus incubation temperature, with $\mathrm{y}$ being the growth rate, $\mathrm{T}=$ incubation temperature, and $\mathrm{a}, \mathrm{b}, \mathrm{c}$ and $\mathrm{d}$, the regression constants. According to the adjusted curve: $\mathrm{y}=-0.0013 \mathrm{~T}^{3}+0.0324 \mathrm{~T}^{2}+0.253 \mathrm{~T}-1.85\left(\mathrm{R}^{2}=\right.$ 0.9932), the estimated maximum growth rate for $P$. oleae isolates in CA medium was $5.8 \mathrm{~mm} \mathrm{day}^{-1}$ at the optimum temperature, estimated in $19.9^{\circ} \mathrm{C}$ (Figure 1a). The maximum growth rate in PDA medium was $2.5 \mathrm{~mm} \mathrm{day}^{-1}$ at the optimum temperature, 
estimated in $20.6^{\circ} \mathrm{C}$ (Figure 1b) according with the adjusted curve $\mathrm{y}=-0.0004 \mathrm{~T}^{3}+$ $0.0084 \mathrm{~T}^{2}+0.164 \mathrm{~T}-0.9933\left(\mathrm{R}^{2}=0.9726\right)$. Isolates did not grow neither at $5^{\circ} \mathrm{C}$ nor at $30^{\circ} \mathrm{C}$ in both culture media.

\section{Isolation frequencies}

Isolation frequencies (percentage of trees with positive isolation) of Phytophthora spp. obtained in 2014 and 2015 from root and soil samples are in Figure 2. All the three Phytopththora spp. (P. cryptogea, P. megasperma and P. oleae) were isolated from roots and rhizosphere soil in both samplings. In 2014, P. cryptogea was the main species associated with symptomatic roots (44\% of positive isolation) and soil samples (36\% of positive isolation); while in 2015 it was replaced by $P$. oleae as the main species in roots (36\% of positive isolation) and rhizosphere ( $40 \%$ of positive isolation). Phytophthora megasperma was isolated from roots and soil in both samplings, but always at low frequencies (Figure 2). More than one Phytophthora spp. were recovered from roots of the same tree at the same sampling, but only from four individuals.

\section{Pathogenicity}

The inoculated wild olive seedlings showed foliar symptoms like those observed in the field: foliar yellowing and wilting, starting at the leaf edges and gradually spreading towards the centre, drop of wilted leaves and twigs dieback. Necrosis and absence of feeder roots were equally observed in the field and in inoculated seedlings.

Average values of foliar symptoms recorded weekly are in Figure 3a. Fourteen weeks after inoculation, final foliar symptoms were significantly higher for wild olives 
251 inoculated with $P$. oleae in comparison with uninoculated controls $(\mathrm{F}=17.59, p=$ 252 0.0005). Respect to the disease progression, ANOVA analysis and comparison of means also indicated that average rAUDPC recorded for foliar symptoms was significantly higher in seedlings inoculated with $P$. oleae than in uninoculated control seedlings $(\mathrm{F}=$ $19.80 ; p=0.0003)$ (Figure 3b).

Mean values of root symptoms at the end of the experiment are in Figure 3c. ANOVA showed significant differences between inoculated and uninoculated wild olives $(\mathrm{F}=$ 56.18; $p<0.0001$ ), and the Tukey's test revealed that $P$. oleae caused a level of root symptoms significantly higher than those recorded for controls. Furthermore, P. oleae was consistently re-isolated from necrotic roots from inoculated seedlings $(16.6 \%$ of positive isolation). No Phytophthora spp. were isolated from roots of uninoculated control seedlings.

\section{Discussion}

The present study shows $P$. oleae as a new pathogen for wild olive, causing root rot in a natural forest at southwestern Spain. This species is added to the other two Phytophthora species (P. cryptogea and P. megasperma) already known causing root rot in wild olive (González et al., 2017a). However, different Phytophthora species have been described causing root rot in olive cultivars in different parts of the world: $P$. citricola (Teviotdale, 2005), P. drechsleri (Teviotdale, 2005), P. inundata (SánchezHernández et al., 2001), P. megasperma (Sánchez-Hernández et al., 2001), P. nicotianae (Vettraino et al., 2009) and P. palmivora (Vettraino et al., 2009).

274 Initially, Po isolates were tentatively identified as P. plurivora (González et al., 2017b), 275 because of their similar morphology (Jung \& Burgess, 2009), although sequence 
276 homology appeared not strong enough (only 95\%). In addition, Po wild olive isolates

277 showed a low optimum temperature $\left(20^{\circ} \mathrm{C}\right)$ when compared with the $25^{\circ} \mathrm{C}$ observed by

278 Jung \& Burguess (2009) for P. plurivora. After the recent description of P. oleae as 279 cause of fruit rot in cultivated olives in southern Italy (Ruano-Rosa et al., 2018), a new 280 molecular analysis (ITS and cox-1 regions) confirmed the identification of Po isolates 281 as $P$. oleae. It is frequent to find records of a Phytophthora spp. causing fruit rots and root rots on woody plants; sometimes in different locations, as $P$. palmivora causing pomegranate fruit rot in India and Greece (Erwin and Ribeiro, 1996; Markakis et al., 2017) but crown and root rot in Turkey (Türkölmez et al., 2016); and sometimes both kind of symptoms occur simultaneously, as P. citrophthora causing fruit and root rot on Citrus spp. (Erwin and Ribeiro, 1996); or P. parasitica as pathogen on papaya fruits and roots in Hawaii (Hunter \& Buddengagen 1969).

In previous samplings carried out in the same area between 2009 and 2013, González et al. (2017a) hypothesized that the root rot pathogen P. cryptogea, a high-temperature species, could be replacing a low-temperature one ( $P$. megasperma) infecting wildolives, considering a global increase in temperatures in the Mediterranean Basin (Lindner et al., 2010). However, the unexpected appearance of a new dominant species of low-temperature as $P$. oleae, led us to consider that it could be favoured by the extremely cold winter temperatures suffered in 2012 (minimum temperatures of $3.1^{\circ} \mathrm{C}$ compared with the historical minimum mean of $6.1^{\circ} \mathrm{C}$ ), likely explaining the prevalence of this species in 2015. The prevalence of two low-temperature species infecting wild olive roots following exceptionally cold winter temperatures 2 years ago, as $P$. megasperma in 2009 (González et al., 2017a) and P. oleae in 2015, could be hypothesized as likely unusual considering the long, hot and dry summers prevailing in the area. However, some Phytophthora spp. with low optimum temperature and ability 
301 to form thick-walled oospores and abundant sporangia, have been described as an adaptation to Mediterranean climates with long, hot and dry summer and wet winters

303 (Brazee et al., 2016; Jung et al., 2017), including P. oleae (Ruano-Rosa et al., 2018).

According with this hypothesis, $P$. oleae would be able to survive severe summer droughts in its dormant state (oospore) and rapidly resume growth and sporulation after autumn-winter rainfalls, acquiring advantage to compete for wild olive root infection when temperatures are cooler than usual. However, the prevalence of $P$. oleae infecting wild olives in the last years could also be a result of its arrival to Spanish natural forests as a new invasive Phythophthora pathogen. Phytophthora oleae was firstly described causing a soft rot of mature olive fruits in a restricted area in Italy (Ruano-Rosa et al., 2018) and, to our knowledge, this is the only report of this pathogen worldwide. Some of the most destructive and well-documented epidemics of trees and forests are caused by alien Phytophthora spp. Moreover, most of the ca. 150 currently known species of Phytophthora were unknown to science before they turned up in other continents as invasive aggressive pathogens of native plants or plantation crops (Jung et al., 2016). Due to a lack of co-evolution between the likely newly introduced $P$. oleae and wild olive, this endemic host can be highly susceptible to the pathogen and this fact could explain why it is replacing native $P$. megasperma and P. cryptogea in natural forests.

$\underline{\text { Parameters commonly used as indirect indicators of the alien origin of a pathogen }}$ include consistent association with diseased common indigenous plant species and proven high aggressiveness to these plants in pathogenicity trials, as determined for $P$. oleae causing root rot of wild olive or fruit rot of cultivated olive (Ruano-Rosa et al., 2018). An stronger indicator is a low genetic variability and close phylogenetic relatedness to other non-native species (Jung et al., 2016). Identical cox1 and ITS1- 
326 Ruano-Rosa et al. (2018), with only one isolate showing a single base insertion in ITS1.

327 Additionally, the five isolates characterized in this work exhibit identical cox1 and ITS

328 sequences. Despite the low genetic variability exhibited by $P$. oleae, which points to its

329 alien origin, the low number of isolates analysed, together with their small area of

330 provenance in Italy (two olive orchards in the same province) and Spain (one wild olive

331 forest), make neccesary additional research to determine

332 For plant biosecurity and disease management, it is of utmost importance to know

333 whether $P$. oleae is indigenous in Europe or it must be considered as a new alien

334 invasive pathogen. Moreover, to know it possible alien origin is of utmost importance to

335 assess the risk of may be-spreading from natural forest stands to olive plantation crops

336 in Spain, although it will not necessarily successfully establish.

337 The likely invasive nature of $P$. oleae, together with increasing rain episodes

338 concentrated in short periods frequent in southern Spain, would allow outbreak

339 infections in wild olive forests, also putting at risk cultivated olive orchards.

\section{Acknowledgements}

With acknowledgement to MINECO, Spain (project CGL2014-56739-R, INTERCAPA) for M González financial support, Mr MA Rosales (Environment and Water Agency, Seville, Spain) and the City Hall of Puebla del Río (Seville, Spain). Treena Burgess from centre for Phytophthora Science and management at Murdoch University, Australia, assisted with the molecular analysis.

\section{References}


351 Arias-Calderón R, Rodríguez-Jurado D, León L, Bejarano-Alcázar J, de la Rosa R, 352 Belaj A, 2015. Pre-breeding for resistance to Verticillium wilt in olive: Fishing in 353 the wild relative gene pool. Crop Protection 75, 25-33.

354

Brazee NJ, Yang X, Hong CX, 2017. Phytophthora caryae sp. nov., a new species recovered from streams and rivers in the eastern United States. Plant Pathology 66, 805-17.

Campbell CL, Madden LV, 1990. Introduction to Plant Disease Epidemiology. New York, NY, USA: John Wiley \& Sons.

Chen DW, Zentmyer GA, 1970. Production of sporangia by Phytophthora cinnamomi in axenic culture. Mycologia 62, 397-402.

Consejería de Agricultura, Pesca y Desarrollo Rural, 2017. Estaciones agrolimáticas, datos meteorológicos. [http://juntadeandalucia.es/agriculturaypesca]. Accessed 20 September 2016.

Cooke DEL, Drenth A, Duncan JM, Wagels G, Brasier CM, 2000. A molecular phylogeny of Phytophthora and related oomycetes. Fungal Genetics and Biology 30, 17-32.

Erwin DC, Ribeiro OK, 1996. Phytophthora diseases worldwide. St. Paul, MN, USA: APS Press.

González M, Pérez-Sierra A, Serrano MS, Sánchez ME, 2017a. Two Phytophthora species causing decline of wild olive (Olea europaea subsp. europaea var. sylvestris). Plant Pathology 66, 941-948.

González M, Pérez-Sierra A, Serrano MS, Sánchez ME, 2017b. A third Phytophthora species causing wild olive decline in Spanish forests. In: Proceedings of the 8th Meeting of the International Union of Forestry Research Organisations, 2017. Sapa, Vietnam: pp. 21. 
Hüberli D, Tommerup IC, Hardy GESJ, 2000. False-negative isolations or absence of lesions may cause mis-diagnosis of diseased plants infected with Phytophthora cinnamomi. Australasian Plant Pathology 29, 164-169.

Hunter JE, Buddenhagen IW, 1969. Field biology and control of Phytophthora parasitica on papaya (Carica papaya) in Hawaii. Annals of Applied Biology 63, 5360.

Jung T, Burgess T, 2009. Re-evaluation of Phytophthora citricola isolates from multiple woody hosts in Europe and North America reveals a new species, Phytophthora plurivora sp. nov. Persoonia. 22, 95-110.

Jung T, Orlikowski L, Henricot B et al., 2016. Widespread Phytophthora infestations in European nurseries put forest, semi-natural and horticultural ecosystems at high risk of Phytophthora diseases. Forest Pathology 46, 134-163.

Jung T, Chang TT, Bakonyi J et al., 2017. Diversity of Phytophthora species in natural ecosystems of Taiwan and association with disease symptoms. Plant Pathology 66, 194-211.

Lindner M, Maroschek M, Netherer S, et al., 2010. Climate change impacts, adaptive capacity, and vulnerabilitty of European forest ecosystems. Forest Ecology and Management 259, 698-709.

Markakis EA, Tzima AK, Palavouzis SC, Antoniou PP, Paplomatas EJ, Tjamos EC, 2017. First report of Phytophthora palmivora causing fruit rot on pomegranate in Greece. Plant disease 101, 1060.

Robideau GP, De Cock AWAM, Coffey MD et al., 2011. DNA barcoding of oomycetes with cytochrome c oxidase subunit I and internal transcribed spacer. Molecular and Ecological Research 11, 1002-1011. 
400 Romero MA, Sánchez JE, Jiménez JJ et al., 2007. New Pythium taxa causing root rot on 401 Mediterranean Quercus species in south-west Spain and Portugal. Journal of 402 Phytopathology 155, 289-95.

403

404

405

406

407

408

409

410

411

412

413

414

415

416

417

418

419

Ruano-Rosa D, Schena L, Agosteo GE, MAgnano di San Lio G, Cacciola SO, 2018. Phytophthora oleae sp. nov. causing fruit rot of olive in southern Italy. Plant Pathology 67, 1362-1373.

Rubio de Casas R, Balaguer L, Manrique E, Pérez ME, Vargas P, 2002. On the historical presence of the wild olives Olea europaea L. var. sylvestris (Miller) Leh. in the Eurosiberian North of the Iberian Peninsula. Anales del Jardín Botánico de Madrid 59, 342-344.

Sánchez ME, Ruiz Dávila A, Pérez De Algaba A, Blanco López MA, Trapero Casas A, 1998. Occurrence and etiology of death of young olive trees in southern Spain. European Journal of Plant Pathology 104, 347-57.

Sánchez-Hernández ME, Muñoz-García M, Brasier CM, Trapero-Casas A, 2001. Identity and pathogenicity of two Phytophthora taxa associated with a new root disease of olive trees. Plant Disease 85, 411-416.

Teviotdale BE, 2005. Diseases of olive. In: Sibbett GS, Ferguson L, eds. Olive Production Manual 2nd ed. Oakland, CA, USA: University of California Agriculture and Natural Resources, 119-222.

Türkölmez S, Çiftçi O, Serçe ÇU, Dervis S, 2016. First report of Phytophthora palmivora causing crown and root rot on pomegranate (Punica granatum) in Turkey. Plant Disease 100, 227.

Vettraino SM, Lucero G, Pizzuolo P, Franceschini S, Vannini A, 2009. First report of root rot and twigs wilting of olive trees in Argentina caused by Phytophthora nicotianae. Plant Disease 93, 765. 
425 White TJ, Bruns T, Lee S, Taylor J, 1990. Amplification and direct sequencing of 426 fungal ribosomal RNA genes for phylogenetics. In: Innis MA, Gelfand DH, Sninsky 427 JJ, White TJ, eds. PCR Protocols: a guide to methods and applications. Academic 428 Press: San Diego, CA, USA, 315-321.

\section{9}

430

431

432

433

434

435

436

437

438

439

440

441

442

443

444

445

446

447

448

449 
450 Figure 1 Growth rate patterns for Phytophthora oleae isolated from wild oilives 451 growing on CA (a) and PDA (b) media. Lines represent the adjusted third degree 452 polynomic model on CA $\left(y=-0.0013 \mathrm{~T}^{3}+0.0324 \mathrm{~T}^{2}+0.253 \mathrm{~T}-1.85 ; \mathrm{R}^{2}=0.9932\right)$ 453 and PDA $\left(y=-0.0004 \mathrm{~T}^{3}+0.0084 \mathrm{~T}^{2}+0.164 \mathrm{~T}-0.9933 ; \mathrm{R}^{2}=0.9726\right)$. Dots are the 454 main values of the observed growth rates. Arrows indicate the estimated optimum 455 growth temperature on $\mathrm{CA}\left(19.9^{\circ} \mathrm{C}\right)$ and $\mathrm{PDA}\left(20.6^{\circ} \mathrm{C}\right)$.

456

457 Figure 2 Percentage of trees with positive isolation of Phytophthora oleae (Po), P. 458 cryptogea $(\mathrm{Pc})$ or P. megasperma $(\mathrm{Pm})$ from roots (a) and rhizosphere soil (b) of 459 symptomatic wild olives sampled in 2014 and 2015.

460

461 Figure 3 Average values and standard errors of foliar symptoms (a), relative area under 462 the disease progress curve (rAUDPC) (b), and root symptoms (c), recorded on wild 463 olives inoculated with $P$. oleae and submitted to periodical soil flooding for 14 weeks. 464 For each graph, values with different letters differ significantly according with Tukey’s 465 HSD test $(p<0.05)$. 
Table 1 Average seasonally minimal and maximal temperatures $\left({ }^{\circ} \mathrm{C}\right)$ between 2007 and 2015. Data obtained from 'La Puebla del Río II' Meteorological station ( $37^{\circ} 04^{\prime} 48^{\prime}$ ' N, $06^{\circ} 02^{\prime} 47^{\prime}$ ' W), Seville, Spain.

\begin{tabular}{|c|c|c|c|c|c|c|c|c|c|c|c|}
\hline & \multirow[t]{2}{*}{ Season } & \multicolumn{9}{|c|}{ Year } & \multirow{2}{*}{$\begin{array}{c}\text { Mean } \\
(2001-2015)\end{array}$} \\
\hline \multirow{5}{*}{ 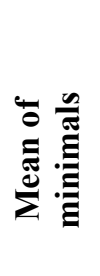 } & & 2007 & 2008 & 2009 & 2010 & 2011 & 2012 & 2013 & 2014 & 2015 & \\
\hline & Winter (Jan-Mar) & 2.9 & 5.6 & 5.8 & 7.9 & 7.0 & 3.1 & 6.8 & 6.8 & 5.1 & 6.1 \\
\hline & Spring (Apr-Jun) & 10.8 & 12.5 & 12.1 & 13.0 & 14.9 & 13.2 & 12.1 & 13.2 & 14.0 & 13.2 \\
\hline & Summer (Jul-Sep) & 16.1 & 16.8 & 17.0 & 17.9 & 17.4 & 16.7 & 18.0 & 16.6 & 16.9 & 17.3 \\
\hline & Autumn (Oct-Dec) & 6.8 & 7.2 & 10.2 & 9.1 & 9.4 & 10.4 & 8.6 & 10.2 & 11.0 & 9.5 \\
\hline \multirow{4}{*}{ 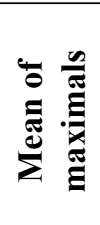 } & Winter (Jan-Mar) & 15.2 & 18.2 & 17.4 & 16.2 & 17.4 & 18.6 & 16.6 & 17.9 & 18.1 & 17.4 \\
\hline & Spring (Apr-Jun) & 24.7 & 26.2 & 27.0 & 26.3 & 28.5 & 27.7 & 26.3 & 27.5 & 28.7 & 27.0 \\
\hline & Summer (Jul-Sep) & 31.2 & 31.5 & 32.6 & 32.9 & 32.1 & 32.2 & 32.3 & 30.3 & 31.9 & 31.7 \\
\hline & Autumn (Oct-Dec) & 19.3 & 18.6 & 21.8 & 19.4 & 21.5 & 20.2 & 20.9 & 20.9 & 21.4 & 20.3 \\
\hline
\end{tabular}


Table 2 Morphological characteristics of Po isolates (Phytophthora oleae)

\begin{tabular}{ll}
\hline Colony morphology on CA $\left(6\right.$ days at $\left.20^{\circ} \mathrm{C}\right)$ & Chrysanthemum \\
& \\
Sexual system & Homothallic \\
Oogonia diameter $(\mu \mathrm{m} \pm \mathrm{SE})$ & $28.8 \pm 0.3$ \\
Oospores & Aplerotic \\
Diameter $(\mu \mathrm{m} \pm \mathrm{SE})$ & $26.8 \pm 0.2$ \\
Oospore wall thickness $(\mu \mathrm{m} \pm \mathrm{SE})$ & $1.5 \pm 0.1$ \\
Antheridia & $0 \%$ \\
$\quad$ Amphigynous & $100 \%$ \\
Paragynous & $6.3 \pm 0.3$ \\
Length $(\mu \mathrm{m} \pm \mathrm{SE})$ & 4.6 \\
Oogonium diam:antheridium length ratio & \\
Sporangia & Obpyriform, ovoid \\
Shape & $39.1 \pm 0.3$ \\
Length $(\mu \mathrm{m} \pm \mathrm{SE})$ & $28.2 \pm 0.3$ \\
Breadth $(\mu \mathrm{m} \pm \mathrm{SE})$ & 1.4 \\
Length: breadth ratio & Semi-papillate \\
Papilla & $6.6 \pm 0.1$ \\
Pore width $(\mu \mathrm{m} \pm \mathrm{SE})$ &
\end{tabular}


a)

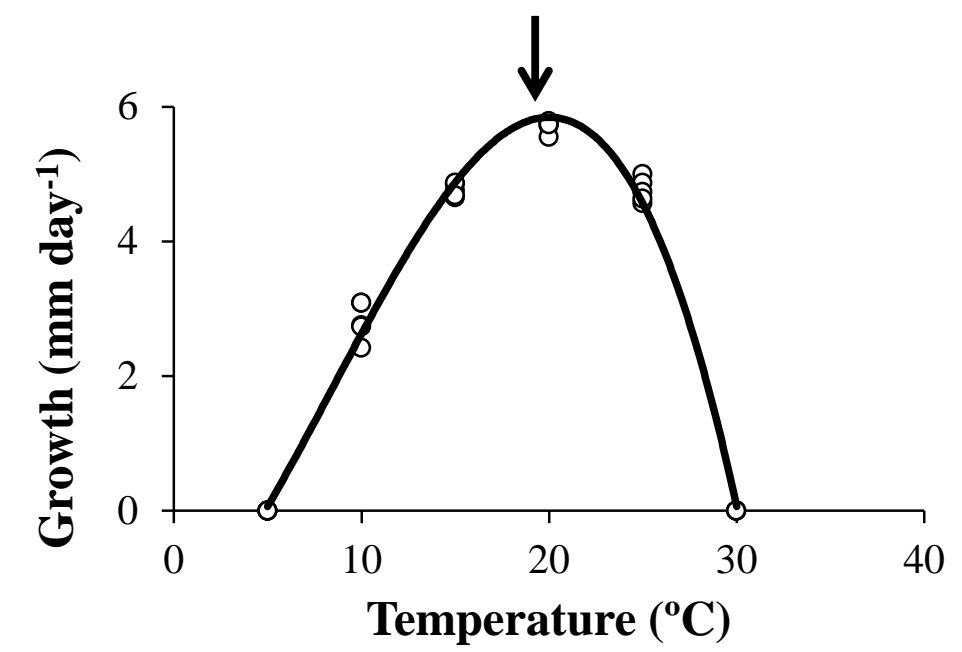

b)

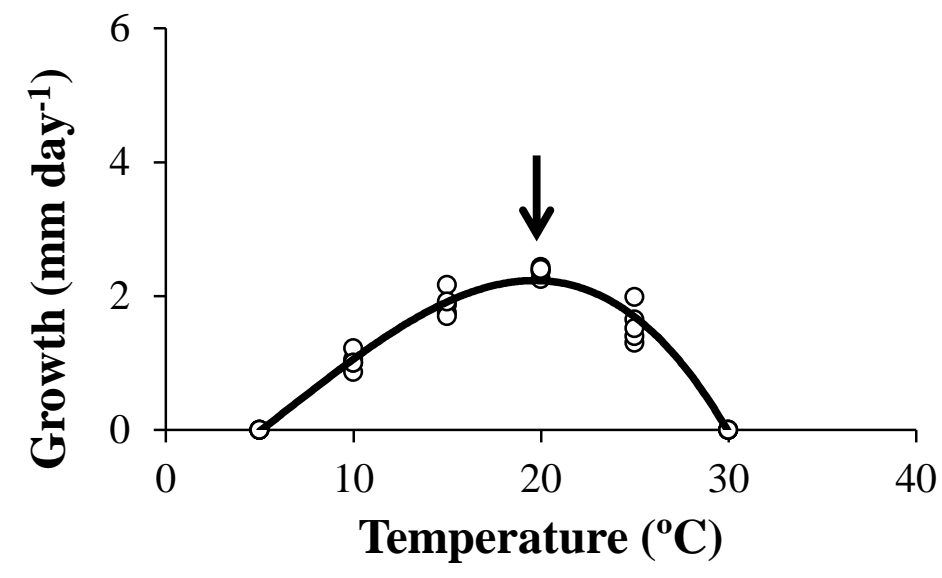




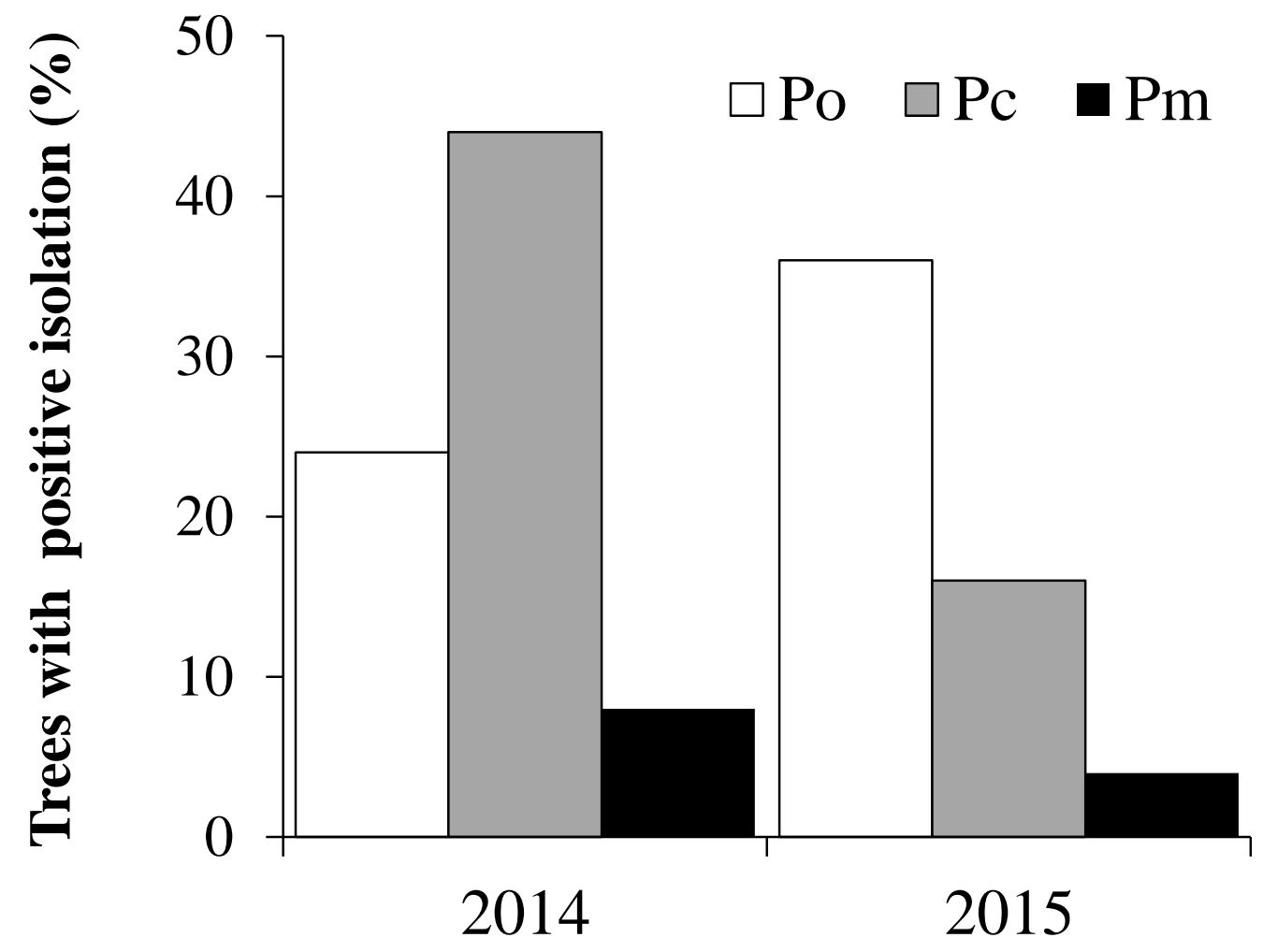

b)

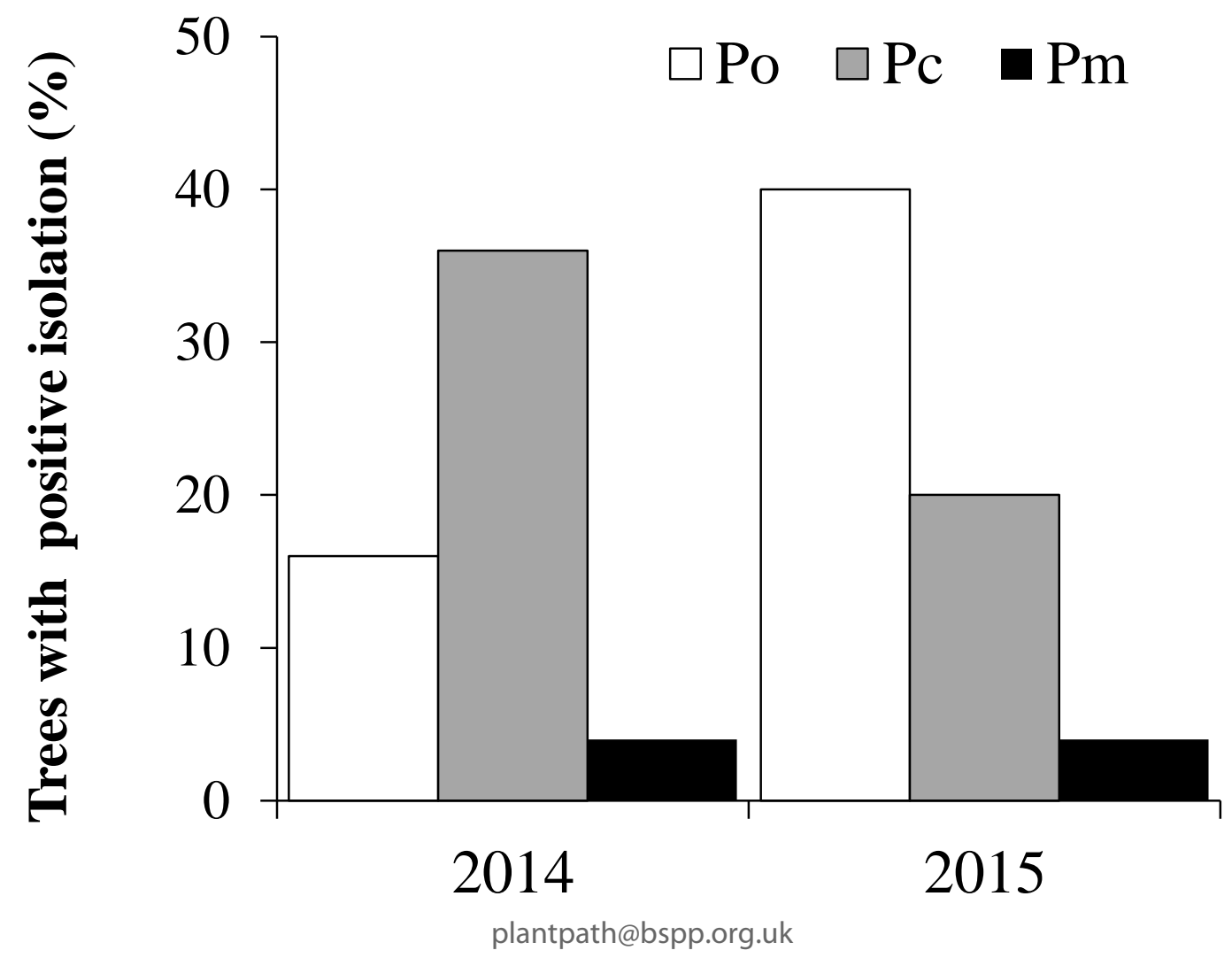


a)

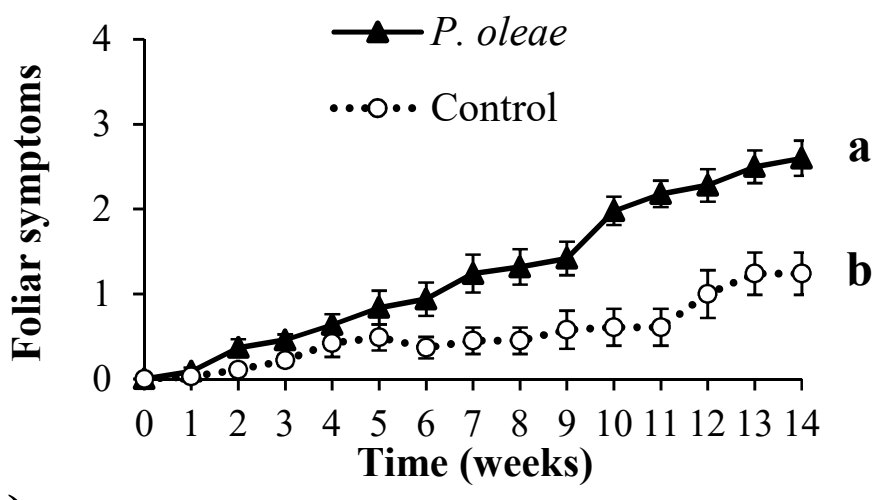

b)

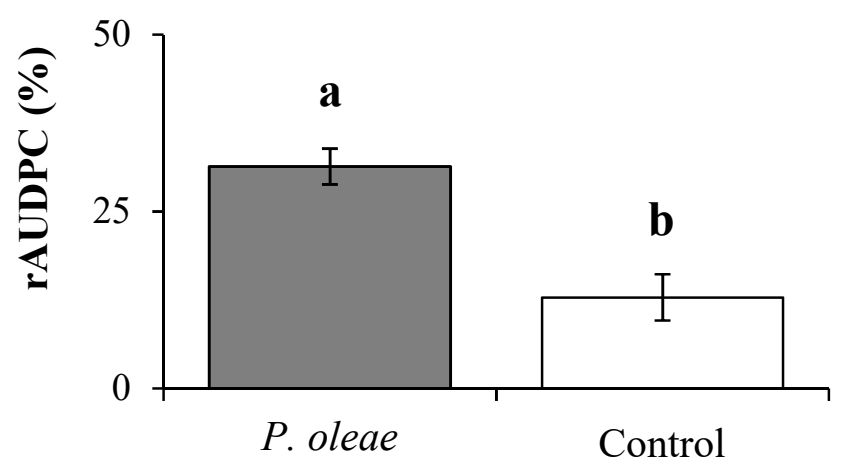

c)

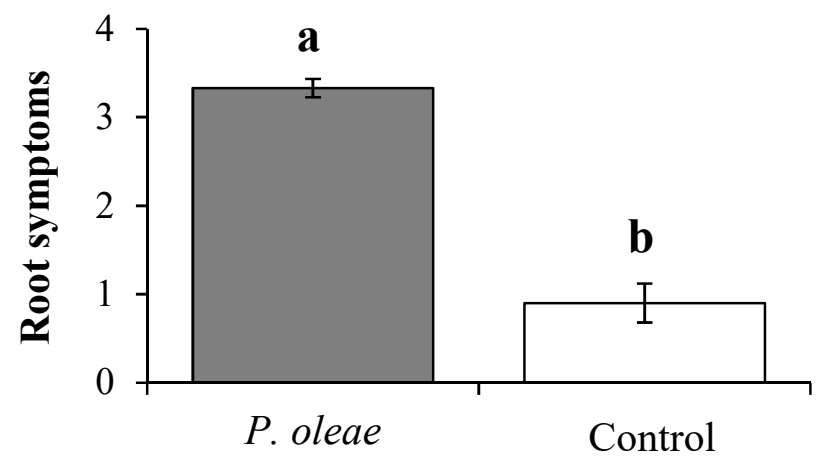

